\title{
Charakterystyka peptydów przeciwdrobnoustrojowych oraz wpływ modyfikacji chemicznych na modulowanie ich aktywności biologicznej
}

\section{STRESZCZENIE}

Ted

ednym z wyzwań, przed którym stoi współczesna nauka jest przezwyciężenie wzrastającej oporności drobnoustrojów na dostępne antybiotyki. Stale rosnąca potrzeba poszukiwania nowych preparatów leczniczych o mechanizmach działania innych niż te dotychczas poznane wynika z powszechnego zjawiska lekooporności wśród chorobotwórczych mikroorganizmów. Przykładem rozwiązania tego problemu może być wykorzystanie peptydów przeciwdrobnoustrojowych (AMP, ang. Antimicrobial Peptides) jako nowych modeli antybiotyków, które charakteryzują się m.in. szerokim zakresem aktywności biobójczej. W niniejszej pracy przedstawiono ogólną charakterystykę peptydów zaliczanych do AMP, a także rolę chemicznych modyfikacji w modulowaniu ich aktywności przeciwdrobnoustrojowej.

\section{WPROWADZENIE}

Obserwowany wzrost antybiotykooporności jest obecnie jednym z głównych problemów zagrażających populacji ludzkiej. Nieodpowiednie stosowanie oraz nadużywanie dostępnych preparatów sprawiło, że ich skuteczność uległa znacznemu osłabieniu przez pojawienie się coraz większej liczby opornych drobnoustrojów [1]. Współcześni naukowcy na szeroką skalę prowadzą badania mające na celu opracowanie skuteczniejszych środków terapeutycznych oddziałujących na patogenne organizmy według mechanizmów obronnych występujących $\mathrm{w}$ naturze $[2,3]$. W ostatnich latach zainteresowanie preparatami peptydowymi znacznie wzrosło ze względu na ich właściwości, takie jak wysoka selektywność, skuteczność działania względem mikroorganizmów i biokompatybilność [4]. Potwierdzają to najnowsze doniesienia informujące, że Amerykańska Agencja Żywności i Leków (US-FDA, ang. United States Food and Drug Administration) zatwierdziła ponad 239 leków białkowych i peptydowych [5,6], które stanowią około $10 \%$ wszystkich farmaceutyków dostępnych na rynku $[7,8]$.

\section{PEPTYDY O WŁAŚCIWOŚCIACH PRZECIWDROBNOUSTROJOWYCH}

Obiecującym sposobem na przezwyciężenie problemu lekooporności mikroorganizmów jest wykorzystanie peptydów przeciwdrobnoustrojowych, które wykazują aktywność wobec szerokiej gamy bakterii Gram-dodatnich, Gram-ujemnych, wirusów i grzybów. Ponadto, część z nich posiada zdolność neutralizacji toksyn bakteryjnych, hamowania reakcji prozapalnych i procesów powstawania biofilmu oraz przyspiesza gojenie ran [9]. AMP są różnorodną strukturalnie grupą związków zbudowanych z 10-50 reszt aminokwasowych. Wypadkowy ladunek mieszczący się $\mathrm{w}$ przedziale od +2 do +9 wynika $\mathrm{z}$ obecności reszt L-argininy, L-lizyny i/lub L-histydyny w łańcuchu peptydowym. Dodatni ładunek oraz amfipatyczność odgrywają istotną rolę w oddziaływaniu AMP z patogenami $[10,11]$.

W organizmach żywych synteza peptydów przeciwdrobnoustrojowych może przebiegać na dwa sposoby: poprzez rybosomalną translację mRNA zachodzącą we wszystkich organizmach oraz nierybosomalną syntezę peptydów przeprowadzaną głównie przez bakterie. Pomimo szerokiego zastosowania AMP otrzymanych na drodze syntezy nierybosomalnej (antybiotyki na bazie polimyksyn i gramicydyny S), naukowcy coraz większą uwagę skupiają na produktach syntezy rybosomalej ze względu na ich istotny udział w stymulowaniu odporności wrodzonej oraz szereg właściwości terapeutycznych [12]. Przez ostatnie dwie dekady zidentyfikowano ponad 3000 naturalnych związków o aktywności przeciwdrobnoustrojowej wyizolowanych z różnych organizmów (Ryc. 1).

Odporność kręgowców wynika z dwóch uzupełniających się mechanizmów: wrodzonego i nabytego. Pierwszy uruchamiany jest najwcześniej i chroni organizmy przed chorobotwórczymi patogenami przez m.in. obniżenie $\mathrm{pH}$ kwasu

\section{Marta Makowska ${ }^{\varpi}$}

prof. dr hab. Adam Prahl,

\section{dr Izabela Małuch}

Katedra Chemii Organicznej, Wydział Chemii, Uniwersytet Gdański

https://doi.org/10.18388/pb.2019_280

๑autor korespondujący: marta.makowska95@ wp.pl

Słowa kluczowe: peptydy przeciwdrobnoustrojowe, modyfikacje chemiczne, lipopeptydy, cyklizacja, aminokwasy nienaturalne, leki

Wykaz stosowanych skrótów:

4-OH-Pip - kwas 4-hydroksypiperazynowy, AMP - peptydy przeciwdrobnoustrojowe (ang. antimicrobial peptides), BPIFA2 - ludzkie białko wydzielnicze ślinianek przyusznych (ang. BPI fold-containing family A member 2), CAMP - kationowe peptydy przeciwdrobnoustrojowe (ang. cationic antimicrobial peptides), CDI - 1,1'-karbonylodiimidazol, CMC - krytyczne stężenie micelarne (ang. critical micellar concentration), LTP - białka zaangażowane $\mathrm{w}$ transport lipidów (ang. plant nonspecific lipid transfer proteins), MIC - minimalne stężenie hamujące (ang. minimal inhibitory concentration), NOH-Val - N-metylo-3-hydroksywalina, Pip - kwas piperazynowy 

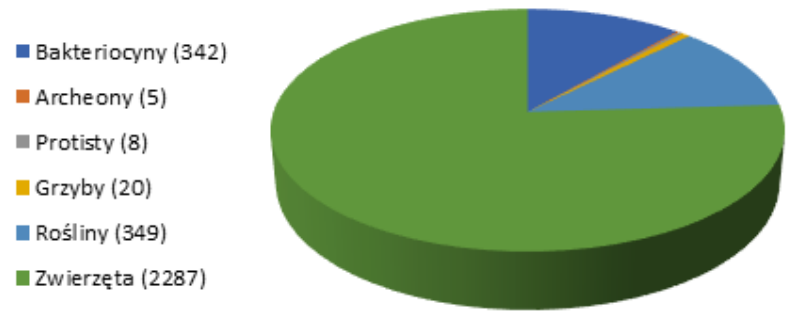

Rycina 1. Organizmy, z których wyizolowano peptydy przeciwdrobnoustrojowe zidentyfikowane do lipca 2019 r. Sporządzono na podstawie [13].

żołądkowego, ruch rzęsek umożliwiający usunięcie drobnoustrojów z dróg oddechowych, a także produkcję kodowanych genetycznie peptydów o aktywności biobójczej [14]. Duża grupa AMP została wyizolowana z ryb, płazów i ssaków, a ich największą ilość zaobserwowano w fagocytach, neurofilach, makrofagach i wydzielinach komórek nabłonkowych $[12,13,15,16]$. Jedną z najistotniejszych rodzin związków o aktywności biobójczej są defensyny ze względu na ich kluczowy udział w modulowaniu odpowiedzi immunologicznej organizmu gospodarza. Poprzez ich bezpośrednią interakcję z komórkami układu odpornościowego, związki te mogą naśladować funkcje chemokinin, a także odpowiadać za ich produkcję zwiększając tym samym liczbę leukocytów i limfocytów wysyłanych prosto do zakażonego miejsca [17].

Defensyny są amfipatycznymi peptydami przeciwdrobnoustrojowymi bogatymi $\mathrm{w}$ reszty aminokwasów zasadowych oraz L-cysteiny, występującymi w organizmach zwierzęcych i roślinnych. Ich aktywność biobójcza skierowana jest względem szerokiej gamy bakterii Gram-dodatnich, Gram-ujemnych i grzybów. Wyróżniamy trzy klasy defensyn: a-, $\beta$ - i $\theta-$, które różnią się między sobą topologią mostków disulfidowych (Ryc. 2) [18]. Pierwsze z nich powstały $\mathrm{z} \beta$-defensyn przez duplikację genów w czasie ewolucji ptaków i niektórych ssaków, a różne ułożenie mostków -S-S- odróżnia obie te klasy od siebie [19]. Najbardziej znanymi a-defensynami są: HNP1-4 (ang. Human Neutrophil Peptide 1-4) produkowane głównie w łożysku, szyjce macicy i błonie śluzowej jelit, związki HD5 (ang. Human Defensin 5) i HD6 występujące w gruczołach ślinowych, ścianie przewodu pokarmowego, moczowego i śluzówce oka oraz NP5 (ang. Neutrophil Peptide 5) obecny w komórkach Panetha [20]. Kilkukrotna duplikacja genów ssaków sprawiła, że $\beta$-defensyny stanowią najbardziej zróżnicowaną klasę AMP. Udowodniono, że związki te kształtowały się najdłużej w toku ewolucji, ponieważ ich obecność wykryto w materiale genetycznym wszystkich dotychczas sklasyfikowanych kręgowców [19]. Przedstawicielami ludzkich $\beta$-defensyn są HBD1-4 (ang. Human $\beta$-Defensin 1-4) zlokalizowane między innymi w błonach śluzowych jamy nosowej i ustnej, osoczu, gruczołach ślinowych i mlekowych, przewodzie pokarmowym, drogach moczowych, moczu, niektórych narządach wewnętrznych i w skórze [20]. Do najpóźniej odkrytych należą $\theta$-defensyny $[19,21]$, do których zaliczane są peptydy RTD1-3 (ang. Rhesus $\theta$-Defensin 1-3) występujące tylko u małp Macaca mulatta $[20,22]$. Defensyny wykazują szerokie spektrum aktywności przeciwdrobnoustrojowej biorąc czynny udział w obronie immunologicznej organizmów, np. ludzka a-defensyna HD5 skutecznie eradykuje zakażenia wywołane przez Salmonella typhimurium i Staphylococcus aureus [18], a RTD-1 wykazuje działanie biobójcze względem Escherichia coli [22].

U roślin AMP odgrywają niezwykle istotną rolę w odporności wrodzonej uczestnicząc $\mathrm{w}$ ich ochronie przed drobnoustrojami, ponieważ organizmy te nie produkują limfocytów B ani T [23]. Peptydy przeciwdrobnoustrojowe znajdują się we wszystkich gatunkach roślin, a ich cechą charakterystyczną jest obecność reszt L-cysteiny (od dwóch do sześciu) i kilku mostków disulfidowych, które przyczyniają się do zachowania zwartej struktury, a także zapewniają odporność proteolityczną i chemiczną [23]. Pod względem budowy roślinne AMP niewiele różnią się od peptydów pozyskanych z organizmów zwierzęcych. Wy-

$\alpha$-defensyny

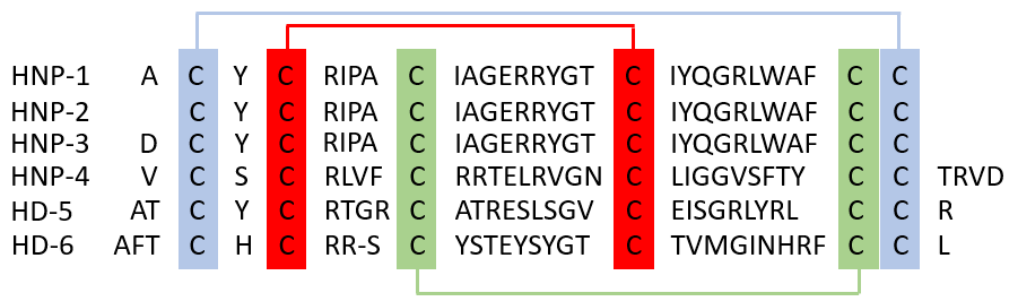

$\beta$-defensyny

\begin{tabular}{|c|c|c|c|c|c|c|c|c|c|c|}
\hline HBD-1 & DHYN & C & VSSGGQ & LYSA & C & PIFTKIQGT & YRGKAK & C & C & K \\
\hline HBD-2 & DPVT & C & LKSGAI & HPVF & C & PRRYKQIGT & GLPGTK & C & C & KKP \\
\hline HBD-3 & QKYY & C & RVRGGR & AVLS & C & LPKEEQIGK & STRGRK & C & C & RRKK \\
\hline HBD-4 & LDRI & C & GYGTAR & RKK & C & RSQEYRIGR & PNTYA & C & C & LRKWDESLLNRTKP \\
\hline
\end{tabular}

$\theta$-defensyny

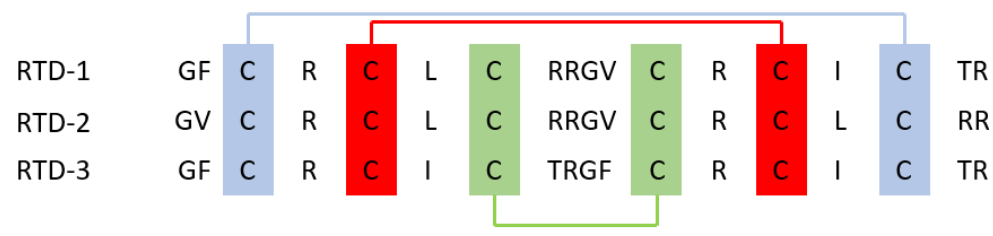

Rycina 2. Sekwencje ludzkich oraz $\theta$-defensyn z zaznaczoną topologią mostków disulfidowych. 


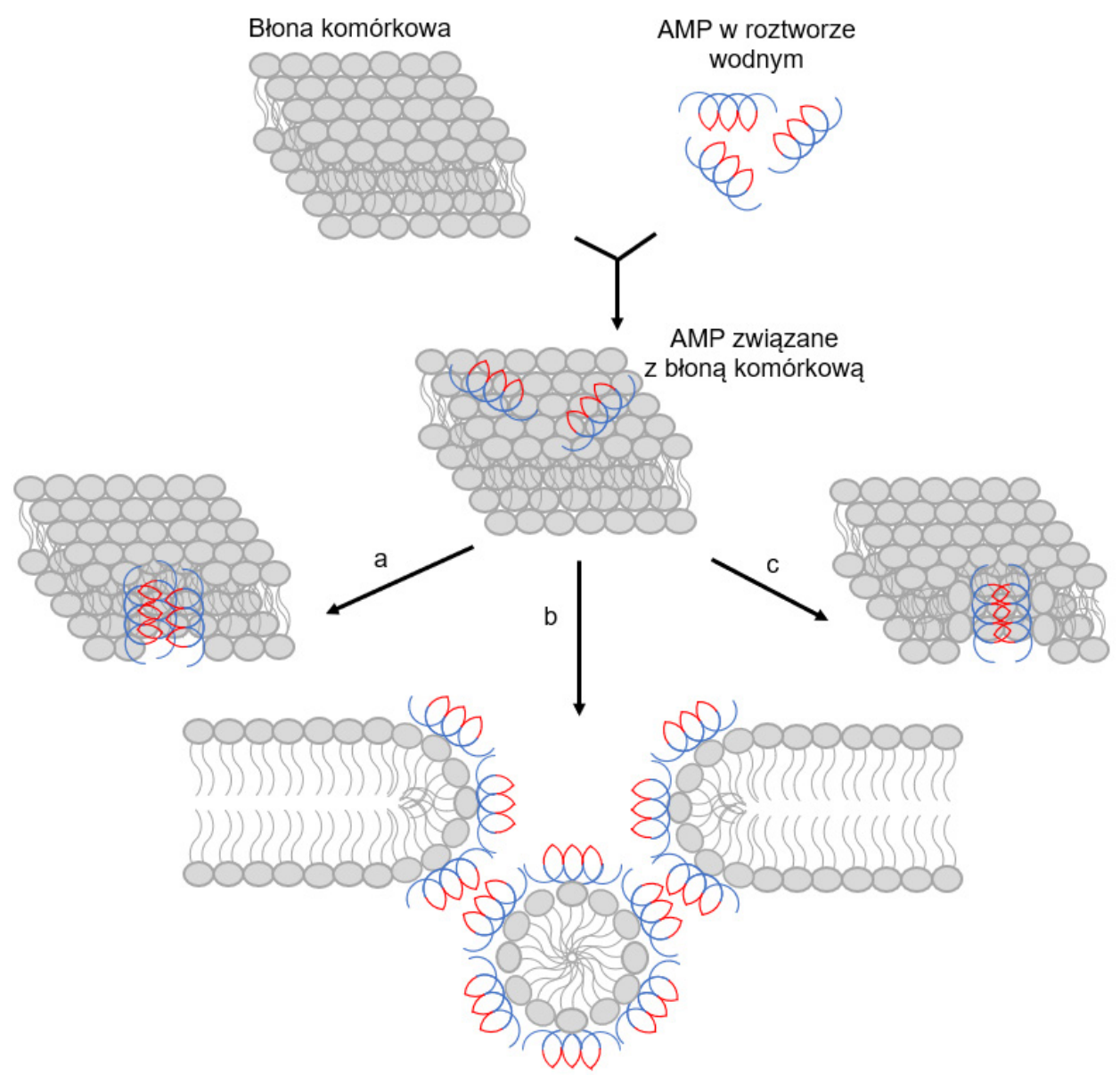

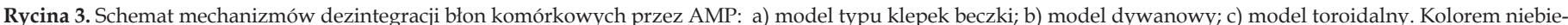
skim oznaczono ugrupowania hydrofobowe, a kolorem czerwonym - hydrofilowe. Sporządzono na podstawie [11].

padkowy ładunek dodatni oraz amfipatyczność determinują ich charakter membranolityczny, a także odpowiadają za nadanie im funkcji ochronnych. Cechy te wykazują dotychczas najdokładniej przebadane rodziny naturalnych AMP: tioniny, defensyny i cyklotydy występujące m.in. w liściach i nasionach $[13,24]$. Pierwsze z nich są niskocząsteczkowymi peptydami przeciwdrobnoustrojowymi zawierającymi od 45 do 47 reszt aminokwasowych w łańcuchu. Wyróżnia się dwie podgrupy tionin: $8 \mathrm{c}$ - posiadające osiem reszt L-cysteiny w sekwencji i tworzących cztery mostki disulfidowe, a także $6 c$ posiadające takich reszt sześć i odpowiednio trzy wiązania -S-S-. Do grona tych AMP należy purotionina wykazująca aktywność względem Ralstonia solanacearum, Xanthomonas phaseoli, Xanthomonas campestris oraz Erwinia amylovora [25]. Kolejną grupą są defensyny zaliczane do kationowych peptydów o aktywności litycznej, w których reszty L-cystein połączone są 4-5 mostkami disulfidowymi [25]. Pozytywny wpływ roślinnych defensyn na eliminację ludzkich patogenów wykazują dwa peptydy: MsDef1 i MtDef4 wyizolowane z lucerny (Medicago sativa), które wstrzymują wzrost Staphylococcus aureus, Staphylococcus epidermidis, Listeria monocytogenes oraz Helicobacter pylori [26]. Ostatnia grupa zwana cyklotydami obejmuje peptydy pochodzenia roślinnego zbudowane z około 30 reszt aminokwasowych i charakteryzujące się unikalną budową strukturalną. Są one cyklicznymi polipeptydami, w których sześć konserwatywnych reszt L-cysteiny tworzy trzy most- ki disulfidowe ułożone $w$ tzw. motyw węzła cysteinowego [27]. Do reprezentantów tej grupy należą kalata B1 oraz cyrkulina-A, które największą aktywność wykazują przeciwko Staphylococcus aureus [27]. Przykładem związków o mechanizmie działania odmiennym od AMP zwierzęcych są peptydy heweinowe (ang. hevein-like peptides) wiążące chitynę, peptydy o strukturze węzła (ang. knottin-type) hamujące aktywność enzymatyczną, a także wykazujące zdolność do zakłócania pracy białek zaangażowanych $\mathrm{w}$ transport lipidów (LTP, ang. plant nonspecific lipid transfer proteins) uniemożliwiając tym samym przenikanie drobnoustrojów przez błony komórkowe $[25,28]$.

Bezkręgowce, podobnie jak rośliny, nie posiadają odporności swoistej, dlatego przed szkodliwym działaniem mikroorganizmów chroni je wrodzony układ odpornościowy. $\mathrm{W}$ organizmach tych AMP obecne są $\mathrm{w}$ hemolimfie, krwinkach białych i czerwonych oraz komórkach nabłonkowych [29]. Szereg bezkręgowców morskich (krewetki, kraby, ostrygi) wytwarza AMP na drodze konstytutywnej ekspresji genów, czyli poprzez ciągłą transkrypcję i translację bialek i peptydów o aktywności przeciwdrobnoustrojowej [13]. Najlepiej poznaną rodziną AMP wyizolowanych z owadów są cekropiny A i B posiadające aktywność lityczną względem Fusarium oxysporum i Aspergillus fumigatus. Steiner ze współpracownikami wyizolował je z ćmy Hyalophora cecropia, zsekwencjonował i scharakteryzował w 1981 roku jako pierwszy [30]. Udowodniono także, że AMP wyizolowane 
z organizmów bezkręgowców wykazują również działanie grzybobójcze: dermaseptyny względem Aspergillus flavus i Aspergillus fumigatus, natomiast Skin-PYY i magaininy przeciwko Candida albicans [31,32]. Z kolei kraby podkowiaste produkują między innymi tachyplesynę, która wykazuje silne działanie biobójcze względem opornych szczepów bakterii (Escherichia coli, Staphylococcus aureus) [33] i grzybów (Candida neoformans) [34] oraz pelipemuzynę dodatkowo hamującą infekcje wywołane wirusem HIV [13,35,36].

Wnikanie AMP do wnętrza komórek bakteryjnych może przebiegać na drodze zróżnicowanych mechanizmów. W większości przypadków zachodzi dezintegracja błon komórkowych mikroorganizmów w procesie lizy poprzez występowanie oddziaływań elektrostatycznych i hydrofobowych pomiędzy dodatnio naładowanymi fragmentami reszt L-argininy i/lub L-lizyny, a obszarami błon bakteryjnych obdarzonymi ładunkiem ujemnym. W przypadku bakterii Gram-dodatnich ładunek ten pochodzi od kwasów tejchojowych połączonych z peptydyloglikanem lub błoną plazmatyczną. Grupy fosforanowe będace elementem struktury opisywanych kwasów odpowiadają za wypadkowy ładunek ujemny. Natomiast fosfolipidy i lipopolisacharydy znajdujące się w zewnętrznej otoczce bakterii Gram-ujemnych determinują silnie ujemny ładunek ich powierzchni. Wyróżnia się trzy główne modele przenikania peptydów przeciwdrobnoustrojowych przez zewnętrzne otoczki drobnoustrojów: klepek beczki, dywanowy i toroidalny [37] (Ryc. 3).

Model klepek beczki (Ryc. 3a) opiera się na oddziaływaniu amfipatycznych peptydów o strukturze a-helikalnej z błoną bakteryjną z utworzeniem kanałów transbłonowych lub porów z hydrofilowymi fragmentami skierowanymi do ich wnętrza. Powoduje to wbudowanie się AMP w szkielet lipidowy membrany w pozycji wertykalnej oraz zakłócenie potencjału transbłonowego i gradientu jonów. W wyniku tych zjawisk zostaje zahamowana synteza ATP oraz wzrasta przepuszczalność błony prowadząc do obrzęku komórek i osmolizy. Wielkość porów oraz ich efektywność zależą od liczby monomerów AMP, która z kolei jest warunkowana przez stężenie peptydu [38,39].

Pierwszy etap mechanizmu dywanowego (Ryc. 3b) polega na związaniu peptydu z błoną i utworzeniu na jej powierzchni „dywanu”. Łańcuchy peptydowe układają się na zewnątrz membrany w taki sposób, aby ich regiony hydrofilowe były zwrócone w stronę hydrofilowych fragmentów fosfolipidów, a hydrofobowe w stronę rdzenia błony. W wyniku obecności oddziaływań elektrostatycznych dodatnio naładowane fragmenty łańcucha peptydowego AMP łączą się z fosfolipidami wykazującymi ładunek ujemny, dochodzi do ograniczenia przepuszczalności błony przez strukturę peptydowego dywanu, a następnie membrana ulega zniszczeniu tworząc ostatecznie struktury micelarne [40].

W modelu toroidalnych porów (Ryc. 3c) AMP agregują na powierzchni dwuwarstwy lipidowej powodując jej zaginanie do wewnątrz. Hydrofilowe regiony łańcucha peptydowego wiążą się z polarnymi głowami lipidów membranowych prowadząc do dezintegracji błony i utworzenia po- rów o większych rozmiarach niż w modelu klepek beczki [41].

\section{PRZYKŁADY CHEMICZNYCH MODYFIKACJI AMP}

Peptydy przeciwdrobnoustrojowe pomimo swoich licznych zalet posiadają również wiele ograniczeń związanych $\mathrm{z}$ ich zastosowaniem. Wysokie koszty otrzymywania oraz niska biodostępność przyczyniły się do projektowania syntetycznych analogów zawierających sekwencję kluczową dla działania przeciwdrobnoustrojowego lub bazujących na natywnych AMP. Wszystkie dotychczas zaproponowane zmiany obejmowały modyfikacje w obrębie łańcucha peptydowego lub łańcucha bocznego reszt aminokwasowych obecnych w sekwencji. Wprowadzenie reszt D-aminokwasowych, lipidacja oraz cyklizacja przyczyniły się do poprawy selektywności, zwiększenia stabilności metabolicznej oraz aktywności biobójczej [18,42].

\section{NIENATURALNE AMINOKWASY}

Jedną z najczęściej stosowanych modyfikacji AMP jest zamiana reszt L-aminokwasów na izomery D. Grupa badawcza pod kierownictwem prof. Zhao wyizolowała z osy Polybia paulista peptyd MPI (IDWKKLLDAAKQIL-NH ${ }_{2}$ ) wykazujący aktywność przeciwdrobnoustrojową wobec bakterii Gram-dodatnich, Gram-ujemnych oraz grzybów [43]. W celu polepszenia stabilności związku i mając na uwadze specyficzność substratową trypsyny, która katalizuje hydrolizę wiązania peptydowego występującego $\mathrm{w}$ sekwencji po resztach L-lizyny i L-argininy, naukowcy zaprojektowali dwa analogi peptydu MPI: jeden zbudowany wyłącznie z reszt D-aminokwasowych (D-MPI), a drugi podstawiony tylko resztami D-lizyny (D-Lys-MPI, IDW-D-Lys-D-Lys-LLDAAKQIL-NH ${ }_{2}$ ). Wyniki badań dowiodły, że obydwa analogi były odporne na proteolizę, ale tylko D-MPI wykazywał aktywność bójczą na poziomie zbliżonym do formy natywnej [13]. Kolejnym przykładem pozytywnego wpływu insercji nienaturalnych reszt aminokwasowych jest peptyd D-magaininowy (GIGKFLHSAKKFGKAFVGEIMNS) [18]. Pomimo braku poprawy aktywności przeciwdrobnoustrojowej analog ten był wysoce odporny na degradację proteolityczną i nie wykazywał aktywności hemolitycznej [18]. Dodatkowo udowodniono, że połączenie wykorzystania dodatnio naładowanych reszt L-argininy $\mathrm{z}$ aminokwasami niebiałkowymi jak, np. L-ornityna (zamiast L-lizyny) również powoduje obniżenie podatności powstałych analogów na proteolizę [44]. Ye z grupą badawczą w swoich badaniach skupili się na utworzeniu analogów

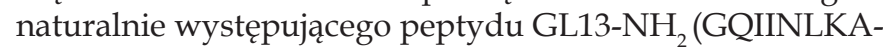
SLDLL-NH ${ }_{2}$, ładunek +1) wyizolowanego z białka BPIFA2 obecnego w ślinie ludzkiej, niewykazującego aktywności bakteriobójczej. W wyniku syntezy otrzymano peptyd GL13K (GKIIKLKASLKLL-NH ${ }_{2}$ ), w którym reszty kwasu asparaginowego, asparaginy i glutaminy podstawiono resztą L-lizyny uzyskując tym samym ładunek +5 oraz właściwości przeciwdrobnoustrojowe, a także jego D-enancjomer. W wyniku przeprowadzonych eksperymentów udowodniono, że L-GL13K skutecznie eliminował zakażenie wywołane bakteriami Pseudomonas aeruginosa, Escherichia coli i Streptococcus gordonii oraz redukował powstały biofilm pierwszej z nich. Natomiast otrzymane wartości MIC (ang. 
a)

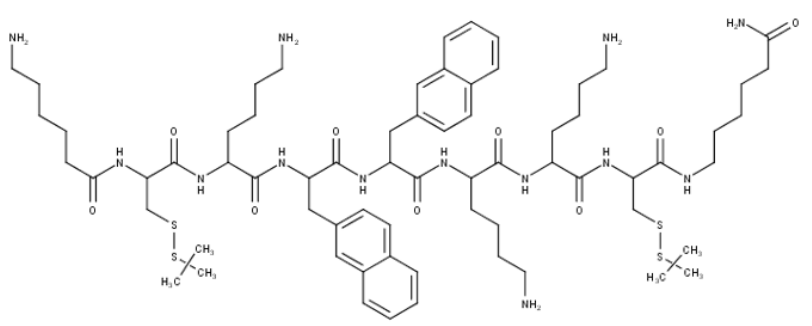

b)

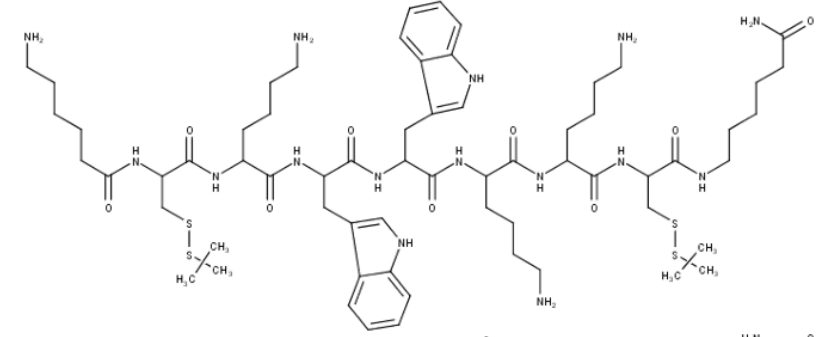

c)

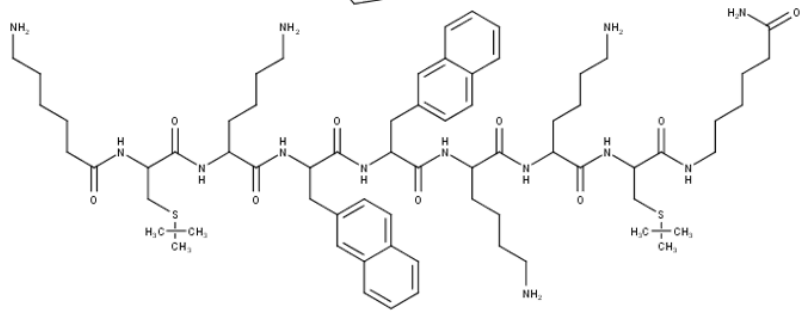

Rycina 4. Wzory strukturalne peptydów a) P9Nal(SS), b) P9Trp(SS), c) P9Nal(SR).

Minimal Inhibitory Concentration) pokazały, że D-GL13K wykazywał znacznie większą aktywność względem bakterii Gram-dodatnich (Enterococcus faecalis, Streptococcus gordonii) $[45,46]$. Z kolei Oliva ze współpracownikami w swojej pracy badawczej skupili się na syntezie trzech peptydów: P9NaI(SS), P9Trp(SS) i P9NaI(SR) (Ryc. 4) o właściwościach zbliżonych do naturalnie występujących kationowych peptydów przeciwdrobnoustrojowych (CAMP) lecz zawierajacych $\mathrm{w}$ swoich sekwencjach nienaturalne aminokwasy (3-(2-naftylo)-L-alaninę i dwie pochodne L-cysteiny z chronionymi grupami tiolowymi (w postaci tioeteru $(\mathrm{Cys}(t \mathrm{Bu}))$ oraz disulfidu (Cys(S-tBu))), a jako grupy kontrolnej użyli peptyd (P)GKY20 [47]. Zabieg ten miał na celu ulepszenie stabilności związków w środowisku proteaz bakteryjnych, a tym samym zwiększenie ich aktywności i wydłużenie okresu półtrwania in vivo. Przeprowadzone testy stabilności w surowicy wykazały, że analogi te cechują się większą odpornością niż naturalne CAMP. Po szesnastogodzinnej inkubacji peptyd P9NaI(SR) stracił aktywność, podczas gdy pozostałe dwa związki w pełni zachowały swoje właściwości. Analog P9NaI(SS) jest najbardziej hydrofobowy spośród badanych, natomiast P9Trp(SS) i P9NaI(SR) posiadają porównywalny stopień hydrofobowości. Grupa we wcześniejszych badaniach udowodniła, że wzrost hydrofobowości skutkuje zwiększoną aktywnością względem bakterii Gram-dodatnich. Ponadto, szczepy Staphylococcus aureus $\mathrm{w}$ celach ochronnych wydzielają proteazy takie jak aureolizyny, stapopainy A i stapopainy B, które są odporne na AMP gospodarza. Na tej podstawie wykazano, że peptyd P9NaI(SS) ze względu na większą hydrofobowość i niższą wrażliwość na proteazy przejawiał większą aktyw- ność biobójczą względem bakterii Gram-dodatnich (Bacillus subtilis spizizenii, Staphylococcus aureus, MRSA), natomiast analogi P9Trp(SS) i P9NaI(SR) działały silniej wobec bakterii Gram-ujemnych (Escherichia coli, Pseudomonas aeruginosa). Kontrargumentem dla pozytywnych wyników badań mikrobiologicznych związku P9NaI(SS) jest jego udowodniona cytotoksyczność wynikająca prawdopodobnie z wyższej hydrofobowości oraz odporności enzymatycznej [47].

\section{LIPIDACJA}

Jedną z ważniejszych modyfikacji potranslacyjnych jest lipidacja, która poza regulowaniem funkcji peptydów i białek, powoduje także zwiększenie ich powinowactwa do błon komórkowych. Zastosowanie zaprojektowanych analogów warunkowane jest przez ilość i rodzaj przyłączonych kwasów tłuszczowych (nasycone lub nienasycone, pojedynczo lub wielokrotnie) oraz długość łańcuchów węglowych [48]. Włączenie grup lipidowych do łańcuchów peptydowych pozwala m.in. na zmianę rozpuszczalności w wodzie nowo zsyntezowanych związków, ich zdolności do samoorganizacji czy stabilności termicznej [49-51]. Mając to na uwadze zaprojektowano grupe polilizynowych lipopeptydów o krótkich sekwencjach potencjalnie wykazujących aktywność przeciwdrobnoustrojową wobec bakterii Gram-dodatnich (Staphylococcus aureus, Staphylococcus epidermidis, Bacillus subtilis, Enterococcus faecalis), Gram-ujemnych (Escherichia coli, Klebsiella pneumoniae, Proteus vulgaris, Pseudomonas aeruginosa) i grzybów (Candida albicans, Candida tropicalis i Aspergillus brasiliensis) [52]. Zsyntezowane analogi różniły się długością łańcucha węglowego (od ośmiu do szesnastu atomów węgla) i wartością wypadkowego ładun$\mathrm{ku}$ dodatniego. Udowodniono, że koniugaty zawierające resztę kwasu palmitynowego $\left(\mathrm{C}_{16}-\mathrm{KK}^{-} \mathrm{NH}_{2}, \mathrm{C}_{16}-\mathrm{KKK}-\mathrm{NH}_{2}\right.$

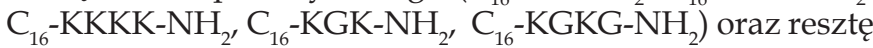
kwasu mirystynowego $\left(\mathrm{C}_{14}-\mathrm{KK}^{2}-\mathrm{NH}_{2}, \mathrm{C}_{14}-\mathrm{KKK}^{-} \mathrm{NH}_{2}\right)$ wykazywały najwyższą aktywność bakteriostatyczną oraz bakteriobójczą względem wszystkich sprawdzanych szczepów. Ponadto wykazano, że analog $\mathrm{C}_{12}-\mathrm{KKKK}_{\mathrm{N}} \mathrm{NH}_{2}$ jako jedyny z całej puli związków posiada aktywność przeciwgrzybiczą [52]. Aktywność lipopeptydów względem bakterii i grzybów zaobserwowano również $\mathrm{w}$ badaniach prowadzonych przez Armasa i współpracowników [53]. Stworzyli oni bibliotekę kationowych peptydów zbudowanych z 4-6 reszt aminokwasowych i bogatych $\mathrm{w}$ reszty L-argininy, które w N-końcowym fragmencie łańcucha peptydowego połączone są z kwasami tłuszczowymi o różnej liczbie atomów węgla $\left(\mathrm{C}_{6}-\mathrm{C}_{14}\right)$. W toku badań autorzy określili, iż sekwencja RFWR jest kluczowa w modulowaniu aktywności biobójczej i na tej podstawie wybrane zostały związki wiodące. Następnie wyznaczając wartości MIC udowodnili, że obecność reszty kwasu laurynowego w cząsteczce potęguje działanie przeciwdrobnoustrojowe względem wszystkich badanych szczepów bakterii (Escherichia coli, Staphylococcus aureus, Pseudomonas aeruginosa, Staphylococcus epidermidis, Enterococcus faecalis, Bacillus subtilis, Listeria monocytogenes, Salmonella typhimurium, Acinetobacter baumannii, Klebsiella pneumoniae, Stenotrophomonas maltophilia, Burkholderia cenocepacia). Przeprowadzone eksperymenty pozwoliły wytypować dwa koniugaty: $\mathrm{C}_{12}$-RIWR-NH $\mathrm{NH}_{2}$ oraz $\mathrm{C}_{12}$-RRIWRR$-\mathrm{NH}_{2}$ jako najbardziej aktywne względem patogennych mikroorganizmów, a w szczególności bakterii Gram-do- 
datnich oraz ich antybiotykoopornym szczepom [53]. Tematem lipopeptydów o krótkich łańcuchach bogatych $\mathrm{w}$ reszty L-argininy zainteresowała się również Sikorska ze współpracownikami [54]. Badacze w swojej pracy skupili się na grupie syntetycznych tetrapeptydów: $\mathrm{C}_{16}-\mathrm{RRRR}-\mathrm{NH}_{2}$, $\mathrm{C}_{14}$-RRRR- $\mathrm{NH}_{2}, \mathrm{C}_{12}$-RRRR-NH ${ }_{2}, \mathrm{C}_{16}$-PRRR- $\mathrm{NH}_{2}$ o potencjalnych właściwościach terapeutycznych. Przeprowadzone testy mikrobiologiczne dowiodły, że wszystkie z koniugatów wykazywały aktywność w zakresie stężeń MIC 1-128 $\mu \mathrm{g} /$ mL ze szczególnym uwzględnieniem wysokiej aktywności przeciwko Staphylococcus epidermidis. Dodatkowo, skrócenie łańcucha węglowego kwasu tłuszczowego powoduje spadek aktywności hemolitycznej i spowalnia wzrost bakterii Gram-dodatnich. Dla wszystkich analogów z wyjątkiem $\mathrm{C}_{16}$-PRRR-NH $\mathrm{N}_{2}$ wartości MIC były znacznie niższe $\mathrm{w}$ porównaniu do krytycznego stężenia micelarnego $(\mathrm{CMC}$, ang. critical micellar concentration), co wskazuje na ich większą aktywność, efektywniejsze ingerowanie w strukturę błon bakteryjnych oraz zwiększenie selektywności [54]. Poza działaniem bakterio- i grzybobójczym lipidowe koniugaty peptydowe również wykazują zdolność do eradykacji biofilmu bakteryjnego, który stanowi większe zagrożenie aniżeli formy planktonowe mikroorganizmów [55]. Takie właściwości posiada między innymi cykliczny syntetyczny lipopeptyd CLP-4 otrzymany z fusaricydyny - środka przeciwgrzybiczego, który skutecznie eliminuje komórki form planktonowych Streptococcus mutans oraz te obecne w wytworzonym biofilmie [56]. Wyniki opisanych badań dowodzą, że mechanizm działania lipopeptydu jest zależny od jego stężenia. Naukowcy przypuszczają, że przy niskich wartościach CLP-4 skutecznie ingeruje $\mathrm{w}$ procesy komórkowe wstrzymując tym samym namnażanie się bakterii, natomiast $\mathrm{w}$ miarę wzrostu stężenia dochodzi do śmierci mikroorganizmu przez zakłócenie integralności błony komórkowej. Ponadto, lipopeptyd cechuje się wysoką stabilnością oraz niską cytotoksycznością, zatem możliwe jest jego realne wykorzystanie $\mathrm{w}$ profilaktyce i leczeniu m.in. próchnicy zębów [55,56].

Długość łańcucha węglowego kwasu tłuszczowego związanego z cząsteczką peptydu $\mathrm{w}$ głównej mierze moduluje jego właściwości antymikrobiotyczne. Zakłada się, że do działania względem bakterii Gram-dodatnich wymagane

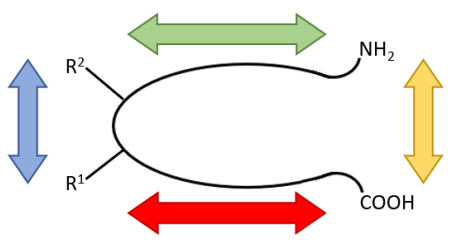

a)

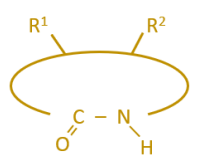

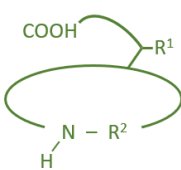

c)

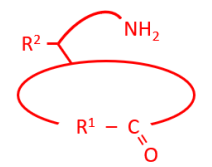

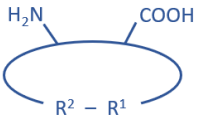

Rycina 5. Rodzaje cyklizacji łańcucha peptydowego z utworzeniem wiązania amidowego: a) głowa-ogon, b) pomiędzy $N$-końcem a grupą funkcyjną w łańcuchu bocznym, c) między $C$-końcem a grupa funkcyjna w łańcuchu bocznym, d) pomiędzy grupami funkcyjnymi zlokalizowanymi w łańcuchach bocznych reszt aminokwasowych; symbolem $\mathrm{R}^{1}$ oznaczono grupę aminową, natomiast $\mathrm{R}^{2}$ - grupę karboksylową.

są dwie reszty metylenowe natomiast $\mathrm{w}$ przypadku bakterii Gram-ujemnych musi ich być znacznie więcej. Zatem hydrofobowość części lipidowej peptydu odpowiada za jego powinowactwo do błony komórkowej drobnoustrojów oraz zakłócenie integralności jej struktury. Natomiast amfifilowość kationowych lipopeptydów warunkuje dwie istotne właściwości: ich asocjację i oligomeryzację. Dzięki temu lipidowe koniugaty wykazują znacznie większą stabilność i odporność proteolityczną [55]. Wyniki przeprowadzonych dotychczas badań dowodzą, jak relacja właściwości hydrofilowo-hydrofobowych wpływa na efektywność w zwalczaniu drobnoustrojów.

\section{CYKLIZACJA}

Znane są cztery rodzaje cyklizacji łańcucha peptydowego naturalnych AMP: pomiędzy $\mathrm{N}$ - i C-końcowym fragmentem łańcucha (tzw. cyklizacja głowa-ogon), N- lub C-końcem łańcucha peptydowego, a grupą funkcyjną zlokalizowaną w łańcuchu bocznym jednego z aminokwasów obecnych w sekwencji oraz w obrębie samych łańcuchów bocznych (Ryc. 5). Efektem tych procesów jest poprawa stabilności peptydu, co przekłada się na większą odporność na degradację $w$ wyniku działania enzymów proteolitycznych.

Tabela 1. Porównanie aktywności przeciwdrobnoustrojowej pochodnych pargamycyny [59]

\begin{tabular}{|c|c|c|c|c|c|}
\hline Mikroorganizm & \multicolumn{5}{|c|}{ MIC $[\mu \mathrm{g} / \mathrm{mL}]$} \\
\hline S. aureus MRSA & 1 & 8 & 4 & 32 & 1 \\
\hline E. faecalis VRE & 1 & 8 & 0,5 & 8 & $>128$ \\
\hline M. luteus & 0,5 & 4 & 1 & 8 & 0,25 \\
\hline B. subtilis & 1 & 8 & 1 & 32 & 0,25 \\
\hline B. cereus & 1 & 8 & 0,5 & 8 & 1 \\
\hline C. bovis & 1 & 8 & 0,5 & 16 & 0,125 \\
\hline E. coli & $>64$ & $>64$ & $>64$ & $>64$ & 128 \\
\hline S. dysenteriae & $>64$ & $>64$ & $>64$ & $>64$ & $>128$ \\
\hline S. enteritidis & $>64$ & $>64$ & $>64$ & $>64$ & $>128$ \\
\hline P. vulgaris & $>64$ & $>64$ & $>64$ & $>64$ & $>128$ \\
\hline P. mirabilis & $>64$ & $>64$ & $>64$ & $>64$ & $>128$ \\
\hline S. marcescens & $>64$ & $>64$ & $>64$ & $>64$ & $>128$ \\
\hline P. aeruginos & $>64$ & $>64$ & $>64$ & $>64$ & $>128$ \\
\hline К. pneumoniae & $>64$ & $>64$ & $>64$ & $>64$ & $>128$ \\
\hline
\end{tabular}


Wykorzystując tę zaletę zaprojektowano dwa peptydy bogate $\mathrm{w}$ reszty L-argininy i L-tryptofanu (RRWWRF-NH $\mathrm{N}_{2}$, z których tylko jeden poddano reakcji cyklizacji [57]. Udowodniono, że cykliczny peptyd wykazywał większą aktywność przeciwdrobnoustrojową względem szczepów Escherichia coli i Bacillus subtilis, a jego działanie było bardziej selektywne niż peptydu liniowego. Hashizume ze współpracownikami skupili się w swoich badaniach na odkryciu antybiotyków działających zarówno na szczep Staphylococcus aureus odporny na metycylinę, jak i Enterococcus faecalis niewrażliwy na wankomycynę (Van) [58,59]. W toku prac badawczych z bulionu fermentacyjnego glebowego szczepu Actinomycete Amycolatopsis sp. wyizolowali cykliczny peptyd (pargamycynę A (PRG-A)) zbudowany z N-metylo-3-hydroksywaliny (NOH-Val), kwasu 4-hydroksypiperazyny (4-OH-Pip), sarkozyny, L-fenyloalaniny, $N$-hydroksyizoleucyny i kwasu piperazynowego (Pip), którego działanie biobójcze udowodniono względem wybranych szczepów drobnoustrojów [58,59]. Dalsze badania doprowadziły naukowców do odkrycia kolejnych aktywnych analogów pargamycyny A: PRG-B, -C i -D. Uzyskane wartości MIC (Tab. 1) porównano $\mathrm{z}$ aktywnością wankomycyny względem bakterii Gram-dodatnich (różne szczepy Staphylococcus aureusi Enterococcus faecalis, Micrococcus luteus, Bacillus subtilis, Bacillus cereus, Corynebacterium bovis) i Gram-ujemnych (Escherichia coli, Shigella dysenteriae, Salmonella enteritidis, Proteus vulgaris, Proteus mirabilis, Serratia marcescens, Pseudomonas aeruginosa, Klebsiella pneumoniae). Wykazano, że PRG-A i -C działały silnie względem bakterii Gram-dodatnich, a aktywność analogów PRG-B i -D była znacznie słabsza. PRG-C i PRG-D, które w swojej strukturze posiadają polarne ugrupowanie Pip przejawiały nawet ośmiokrotnie niższe działanie względem szczepów gronkowców i enteroków niż PRG-A i PRG-B, których wpływ biobójczy był porów-

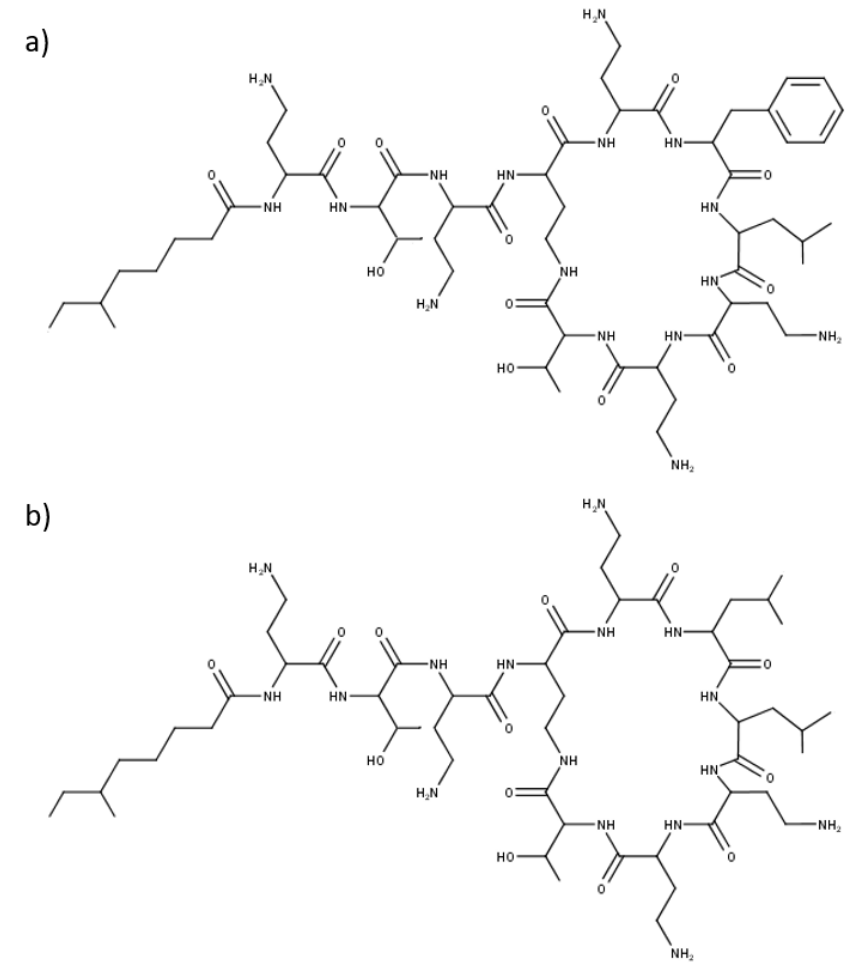

Rycina 6. Wzór strukturalny: a) polimyksyny B, b) polimyksyny E. nywalny. Dodatkowo, dla żadnego z cyklopeptydów oraz wankomycyny nie udowodniono aktywności względem bakterii Gram-ujemnych [59].

$\mathrm{Na}$ rynku farmaceutycznym obecne są antybiotyki peptydowe z grupy polimyksyn (polimyksyna B i E) (Ryc. 6). Są to cykliczne kationowe lipopeptydy o działaniu biobójczym względem bakterii Gram-ujemnych (Acinetobacter, Pseudomonas aeruginosa, Klebsiella pneumoniae, Enterobacter species, Escherichia coli, Citrobacter, Morganella, Haemophilus influenzae) i niektórych szczepów Stenotrophomonas maltophilia. Leki te wykorzystywane są m.in. przy oparzeniach skórnych, pielęgnacji ran pooperacyjnych czy zapobieganiu infekcji. Pomimo udowodnionego działania leczniczego, polimyksyny wykazują wysoką nefro- i neurotoksyczność, dlatego mogą być stosowane jedynie doraźnie [60].

\section{KONIUGATY Z LEKAMI}

Kolejnym typem chemicznej modyfikacji AMP jest kowalencyjne związanie $\mathrm{z}$ antybiotykami, co poprawia ich działanie przeciwdrobnoustrojowe oraz skutkuje zmniejszeniem terapeutycznej dawki leku eliminując tym samym wystąpienie efektów niepożądanych. Podejście to zostało zastosowane przez grupę badawczą z Uniwersytetu Farmaceutycznego w Chinach, która łącząc ubikwicydynę $\left(\mathrm{UBI}_{29-41}\right)$, kationowy peptyd o działaniu biobójczym względem Staphylococcus aureus, Escherichia coli i Pseudomonas aeruginosa z najbardziej powszechnym antybiotykiem, chloramfenikolem (CAP), uzyskała nowy koniugat o zwiększonym działaniu względem Escherichia coli i Staphylococcus aureus (Tab. 2) [61]. Dodatkowo, CAP-UBI $29-41$ wykazywał niższą toksyczność względem komórek ludzkich (L02, HBL-100 i HELF) niż sam chloramfenikol [61].

Jelinkova wraz ze współpracownikami opisała w swojej pracy koniugat Van/Hec (Ryc. 7) składający się z wankomycyny (Van) oraz peptydu Hekate (Hec) o właściwościach biobójczych [62]. Wankomycyna uznawana jest za antybiotyk ostatniej szansy w leczeniu zakażeń wywołanych bakteriami Gram-dodatnimi. Z uwagi na szerzące się zjawisko oporności na jej działanie szczepów Staphylococcus aureus, naukowcy podjęli dalsze próby opracowania nowego sposobu przezwyciężenia tego problemu. Do tego celu wykorzystali peptyd Hec należący do grupy AMP (wykazujący aktywność względem bakterii Gram-dodatnich) posiadający zdolności membranolityczne. Opisywany glikopeptyd zbudowany z 23 reszt aminokwasowych (FALALKALKKALKKLKKALKKAL) jest pochodną melityny wchodzącej w skład jadu pszczelego. Jego budowa oraz właściwości takie jak: amfipatyczna struktura a-helisy, wypadkowy ładunek dodatni i duża liczba reszt aminokwasowych o hydrofobowym charakterze łańcucha bocznego są charakterystyczne dla grupy peptydów o aktywności bakteriobójczej. Naukowcy przyłączając do wankomycyny peptyd Hekate

Tabela 2. Porównanie wartości MIC dla koniugatu $\left(\mathrm{CAP}-\mathrm{UBI}_{29.41}\right)$ i chloramfenikolu (CAP) [61].

$\begin{array}{lll}\text { Mikroorganizm } & \begin{array}{l}\text { MIC }[\mu \mathrm{mol} / \mathrm{L}] \\ \mathrm{CAP} \mathrm{UBI}_{29-41}\end{array} & \mathrm{CAP} \\ \text { E. coli } & 3,8 \pm 0,9 & 6,2 \pm 1,7 \\ \text { S. aureus } & 15,0 \pm 2,6 & 24,8 \pm 5,7\end{array}$




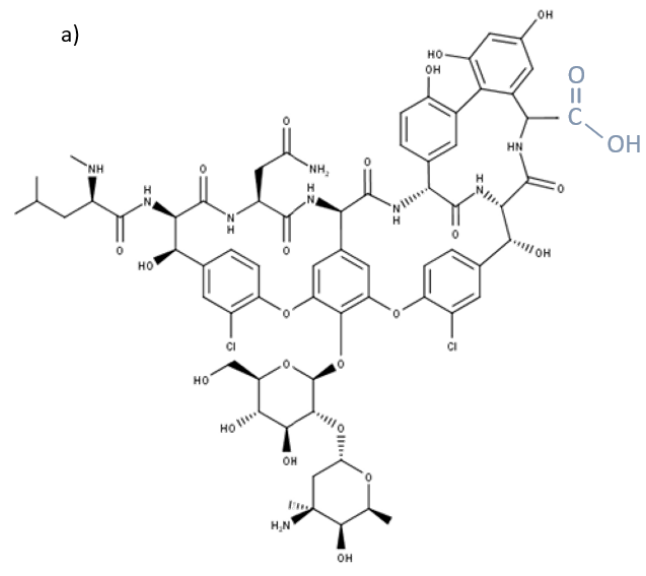

b)<smiles>CCCCCCCCC(C)C</smiles>

c)

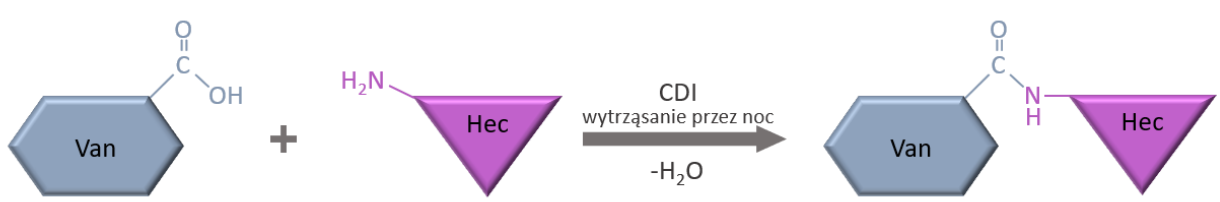

Rycina 7. a) wzór strukturalny wankomycyny (Van), b) sekwencja peptydu Hekate (Hec), c) schemat reakcji otrzymywania koniugatu Van/Hec.

(odpowiednio przez grupę karboksylową i N-końcową aminową) z wykorzystaniem 1,1'-karbonylodiimidazolu (CDI) uzyskali związek o zwiększonej aktywności.

Przeprowadzone testy mikrobiologiczne wykazały, że koniugat ten posiadał znacznie silniejsze właściwości biobójcze względem Staphylococcus aureus (typu dzikiego, VRSA i MRSA) niż sama wankomycyna i Hec (Tab. 3). Dodatkowo, Van/Hec nie jest toksyczny dla komórek nabłonkowych oraz ludzkich erytrocytów, dzięki czemu postrzegany jest jako innowacyjny antybiotyk w leczeniu zakażeń wywołanych przez oporne szczepy gronkowców [62].

Podobne rozwiązanie dla poprawy aktywności antybiotyku i AMP zaproponowała grupa naukowa kierowana przez Tiwari [63]. W swoich badaniach wykorzystali lewofloksacynę stosowaną w leczeniu pozaszpitalnego zapalenia płuc, ostrego bakteryjnego zapalenia zatok i odmiedniczkowego zapalenia nerek, jej nieaktywną pochodną - lewofloksacynę-Q oraz cykliczny peptyd penetrujący (CPP, ang. cell-penetrating peptide) $\left[\mathrm{R}_{4} \mathrm{~W}_{4}\right]$ zbudowany $\mathrm{z}$ reszt L-argininy oraz L-tryptofanu. Badania dowiodły, że peptyd ten w połączeniu z tetracykliną wykazywał aktywność bakteriobójczą względem MRSA 4-8-krotnie większą niż sam antybiotyk (MIC = $0,5 \mu \mathrm{g} / \mathrm{mL})$ i 2-8-krotnie wyższą przeciwko E. coli $(\mathrm{MIC}=$ $2 \mu \mathrm{g} / \mathrm{mL})[63,64]$. Na podstawie tych informacji naukowcy zaprojektowali kolejne cykliczne i liniowe koniugaty oraz mieszaniny fizyczne: lewofloksacyna $+\left[\mathrm{R}_{4} \mathrm{~W}_{4}\right]$ i lewofloksacyna-Q+[ $\left.\mathrm{R}_{4} \mathrm{~W}_{4}\right][63]$. Działanie przeciwbakteryjne nowych

Tabela 3. Porównanie wartości minimalnego stężenia hamującego dla poszczególnych związków [62].

$\begin{array}{llll}\text { Mikroorganizm } & & \text { MIC }[\mu \mathrm{M}] & \\ & \text { Van/Hec } & \text { Hec } & \text { Van } \\ \text { S. aureus } & 0,5 & >80 & 0,6 \\ \text { MRSA } & 3,5 & >80 & 5 \\ \text { VRSA } & 5,0 & >80 & >80\end{array}$

koniugatów badano względem opornego na metycylinę gronkowca złocistego i pałeczki zapalenia płuc, a jako antybiotyki kontrolne dodatkowo zastosowano meropenem i wankomycynę. Przeprowadzone testy mikrobiologiczne dowiodły, że mieszanina lewofloksacyna $+\left[\mathrm{R}_{4} \mathrm{~W}_{4}\right]$ działała silniej niż koniugat antybiotyku i peptydu (Tab. 4). Niezwiązana lewofloksacyna-Q wykazywała aktywność przy stężeniu wyższym niż $128 \mu \mathrm{g} / \mathrm{mL}$ przeciwko MRSA i $K$. pneumoniae, które z kolei uległy znacznej poprawie w przypadku mieszaniny/koniugatu odpowiednio do 8 i $32 \mu \mathrm{g} /$ $\mathrm{mL}$. Natomiast odwrotny efekt zaobserwowano dla wolnej lewofloksacyny, której działanie przejawiało się przy dużo niższych wartościach MIC niż w formach związanych [63]. Uzyskane wyniki sugerują, że amfifilowe cykliczne peptydy penetrujące związane kowalencyjnie $z$ antybiotykami mogą zapewnić bardziej skuteczne działanie biobójcze przeciwko opornym szczepom w porównaniu z terapią niezwiązanymi antybiotykami $[63,64]$.

Tabela 4. Wyznaczone wartości MIC względem bakterii Gram-dodatnich i Gram-ujemnych [63].

\begin{tabular}{lll}
\hline Związek & $\begin{array}{l}\text { MIC }(\mu \mathrm{g} / \mathrm{mL}) \\
\text { MRSA }\end{array}$ & K. pneumoniae \\
\hline Meropenem & nieaktywny & 1 \\
\hline Wankomycyna & 1 & nieaktywny \\
\hline $\begin{array}{l}\text { Lewofloksacyna } \\
\text { Lewofloksacyna-Q }\end{array}$ & 2 & 4 \\
\hline $\begin{array}{l}\text { [R4W4] } \\
\text { Koniugat cykliczny }\end{array}$ & 4 & $>128$ \\
[R4W4]-lewofloksacyna & 32 & 16 \\
$\begin{array}{l}\text { Koniugat liniowy [R4W4]- } \\
\text { lewofloksacyna }\end{array}$ & 64 & $>128$ \\
\hline $\begin{array}{l}\text { Lewofloksacyna+[R4W4] } \\
\text { Lewofloksacyna-Q+[R4W4] }\end{array}$ & 8 & $>128$ \\
$\begin{array}{l}\text { Koniugat cykliczny [R4W4]- } \\
\text { lewofloksacyna-Q }\end{array}$ & 8 & 32 \\
\hline $\begin{array}{l}\text { Koniugat liniowy [R4W4]- } \\
\text { lewofloksacyna-Q }\end{array}$ & nie wyznaczono & nie wyznaczono \\
\hline
\end{tabular}




\section{WYKORZYSTANIE FOTOSENSYBILIZATORÓW}

Wśród metod zwalczania chorób wywołanych drobnoustrojami wyróżnić można również terapię fotodynamiczną, w której działając promieniowaniem o odpowiedniej długości fali na fotouczulacz wytwarzane są reaktywne formy tlenu. Następnie wolne rodniki uszkadzają podstawowe elementy budulcowe komórek (kwasy nukleinowe, białka, lipidy) prowadząc do ich śmierci. Przykładem opisanego typu modyfikacji jest przyłączenie eozyny Y (fotouczulacza) do $N$-końcowego fragmentu peptydu KLA (o sekwencji: (KLAKLAK) ${ }_{2}$ ) wykazującego aktywność przeciwdrobnoustrojową wobec Escherichia coli, Pseudomonas aeruginosa i Staphylococcus aureus [65]. Skoniugowanie eozyny Y z typowym peptydem AMP miało na celu zwiększenie jej aktywności fotodynamicznej, a także umożliwiło penetrację błon komórkowych badanych bakterii Gram-dodatnich (Staphylococcus aureus, Staphylococcus epidermidis) i Gram-ujemnych (Escherichia coli, Pseudomonas aeruginosa, oporny szczep Acinetobacter baumannii) [65,66]. Działanie biobójcze sprawdzano w warunkach bezświetlnych i po 30 minutowej inkubacji światłem o długości fali $525 \mathrm{~nm}$, odpowiadającej maksimum wzbudzenia eozyny $\mathrm{Y}$, która została użyta jako kontrola. Wyniki przeprowadzonych badań dowiodły, że obecność promieniowania nie wpływała znacząco na żywotność komórek bakteryjnych, gdy opisywane związki występowały w postaci wolnej. To samo zaobserwowano w ciemności dla eozyny-(KLAKLAK). Dopiero odpowiednio długa ekspozycja na promieniowanie inicjowała proces aktywacji fotouczulacza, co pozwoliło wyeliminować 99,9\% komórek bakteryjnych przy stężeniu roztworu analogu $1 \mu \mathrm{M}$. Dalsze badania dowiodły, że koniugat fotouczulacz-peptyd lokował się w błonach komórkowych obu klas bakterii, a po jego napromieniowaniu dochodziło do niszczenia zewnętrznych otoczek drobnoustrojów i ich śmierci $[66,67]$.

\section{PODSUMOWANIE}

Jednym z wiodących problemów współczesnej medycyny jest częste stosowanie antybiotyków, co skutkuje kształtowaniem nowych, opornych względem nich gatunków mikroorganizmów. Sposobem wyeliminowania narastającego problemu może być zastosowanie peptydów przeciwdrobnoustrojowych będących elementem układu odporności wrodzonej organizmu. Mianem AMP najczęściej określa się związki obdarzone dodatnim ładunkiem oraz o amfipatycznej budowie, która odpowiedzialna jest za modulowanie ich właściwości przeciwdrobnoustrojowych wobec szerokiej gamy bakterii, wirusów i grzybów. Ze względu na występowanie specyficznych oddziaływań elektrostatycznych i hydrofobowych pomiędzy dodatnio naładowanymi resztami L-lizyny i L-argininy obecnymi często w sekwencjach syntetycznych AMP, a ujemnie naładowanymi błonami komórkowymi bakterii, związki te mogą prowadzić do dezintegracji zewnętrznych otoczek drobnoustrojów na drodze trzech różnych mechanizmów: klepek beczki, dywanowego i toroidalnego. Wysokie koszty produkcji i ograniczona biodostępność naturalnych AMP wymusiły konieczność poszukiwania nowych związków modelowych, których działanie opiera się na dotychczas poznanych mechanizmach. Chemiczne modyfikacje AMP umożliwiają zmianę ich właściwości fizykochemicznych, takich jak lipofilowość, a także wpływają na zwiększenie ich odporności enzymatycznej, co jest ważnym aspektem w projektowaniu nowoczesnych leków peptydowych.

\section{PIŚMIENNICTWO}

1. Veltri D, Kamath U, Shehu A (2018) Deep learning improves antimicrobial peptide recognition. Bioinformatics 34: 2740-2747

2. Manzini MC, Perez KR, Riske KA, Bozelli JC Jr, Santos TL, da Silva MA, Saraiva GK, Politi MJ, Valente AP, Almeida FC, Chaimovich H, Rodrigues MA, Bemguerer MP, Schreier S, Cuccovia IM (2014) Peptide : lipid ratio and membrane surface charge determine the mechanism of action of the antimicrobial peptide BP100. Conformational and functional studies. Biochim Biophys Acta 1838: 1985-1999

3. Lee H, Hwang JS, Lee J, Kim JIl, Lee DG (2014) Scolopendin 2, a cationic antimicrobial peptide from centipede, and its membrane-active mechanism. Biochim Biophys Acta 1848: 634-64

4. Otvos, L, Wade, JD (2014) Current challenges in peptide-based drug discovery. Front Chem 2: 62; doi: 10.3389/fchem.2014.00062

5. Usmani SS, Bedi G, Samuel JS, Singh S, Kalra S, Kumar P, et al. (2017) THPdb: database of FDA-approved peptide and protein therapeutics. PLoS One 12: e0181748; doi: 10.1371/journal.pone.0181748

6. Fosgerau K, Hoffmann T (2015) Peptide therapeutics: current status and future directions. Drug Discov Today 20: 122-128

7. Bruno BJ, Miller GD, Lim CS (2013) Basics and recent advances in peptide and protein drug delivery. Ther Deliv 4: 1443-1467

8. Agrawal P, Raghava GPS (2018) Prediction of antimicrobial potential of a chemically modified peptide from its tertiary structure. Front Microbiol 9: 2551; doi: 10.3389/fmicb.2018.02551

9. Haney EF, Mansour SC, Hancock RE (2017) Antimicrobial peptides: an introduction. Methods Mol Biol 1548: 3-22

10. Nakatsuji T, Gallo RL (2012) Antimicrobial peptides: old molecules with new ideas. J Invest Dermatol 132: 887-895

11. Bahar AA, Ren D (2013) Antimicrobial peptides. Pharmaceuticals (Basel) 6: 1543-1575

12. Mahlapuu M, Håkansson J, Ringstad L, Björn C (2016) Antimicrobial peptides: an emerging category of therapeutic agents. Front Cell Infect Microbiol 6: 194; doi: 10.3389/fcimb.2016.00194

13. Kumar P, Kizhakkedathu JN, Straus SK (2018) Antimicrobial peptides: diversity, mechanism of action and strategies to improve the activity and biocompatibility in vivo. Biomolecules 8: 4; doi: 10.3390/ biom8010004

14. Diamond G, Beckloff N, Weinberg A, Kisich KO (2009) The roles of antimicrobial peptides in innate host defense. Curr Pharm Des 15: 2377-2392

15. Yang D, Biragyn A, Kwak LW, Oppenheim JJ (2002) Mammalian defensins in immunity: more than just microbicidal. Trends Immunol 26: 291-296

16. Bowdish DME, Davidson DJ, Lau YE, Lee K, Scott MG, Hancock REW (2004) Impact of LL-37 on anti-infective immunity. J Leukoc Biol 77: $451-459$

17. Bowdish DME, Davidson DJ, Hancock REW (2006) Immunomodulatory properties of defensins and cathelicidins. Curr Top Microbiol Immunol 306: 27-66

18. Mojsoska B, Jenssen H (2015) Peptides and peptidomimetics for antimicrobial drug design. Pharmaceuticals (Basel) 8: 366-415

19. Xiao Y, Hughes AL, Ando J, Matsuda Y, Cheng JF, Skinner-Noble D, Zhang G (2004) A genome-wide screen identifies a single $\beta$-defensin gene cluster in the chicken: implifications for the orgin and evolution for mammalian defensins. BMC Genomics 5: 56; doi: 10.1186/14712164-5-56

20. Niedźwiedzka-Rystwej P, Deptuła W (2008) Defensyny - ważny wrodzony element układu odpornościowego u ssaków. Postepy Hig Med Dosw 62: 524-529

21. Chen X, Niyonsaba F, Ushio H, Hara M, Yokoi H, Matsumoto K, Saito H, Nagaoka I, Ikeda S, Okumura K, Ogawa H (2007) Antimicrobial 
peptides human $\beta$-defensin (hBD)-3 and hBD-4 activate mast cells and increase skin vascular permeability. Eur J Immunol 37: 434-444

22. Lehrer R, Cole AM, Selsted ME (2012) $\theta$-Defensins: cyclic peptides with endless potential. J Biol Chem 287: 27014-27019

23. Tam JP, Wang S, Wong KH, Tan WL (2015) Antimicrobial peptides from plants. Pharmaceuticals (Basel) 8: 711-757

24. Craik DJ (2012) Host-defense activities of cyclotides. Toxins (Basel) 4: 139-156

25. Yamuna S, Nithesh Kumar V, Bala Subramaniam D, Kumaravel K (2019) Antimicrobial peptides from plants and their mode of action. AIJRSTEM; ISSN: 2328-3580

26. Kaewklom S, Wongchai M, Petvises S, Hanpithakphong W, Aunpad R (2018) Structural and biological features of a novel plant defensin from Brugmansia x candida. PLoS ONE 13: e0201668; doi: 10.1371/journal. pone. 0201668

27. Gruber CW, Čemažar M, Anderson MA, Craik DJ (2007) Insecticidal plant cyclotides and related cystine knot toxins. Toxicon 49: 561-575

28. Nawrot R, Goździcka-Józefiak A (2007) Niskocząsteczkowe białka obronne roślin. Biotechnologia 2: 27-41

29. Jenssen H, Hamill P, Hancock REW (2006) Peptide antimicrobial agents. Clin Microbiol Rev 19: 491-511

30. Steiner H, Hultmark D, Engström, Bennich H, Boman HG (1981) Sequence and specificity of two antibacterial proteins involved in insect immunity. Nature 292: 246-248

31. De Lucca A, Walsh TJ (1999) Antifungal peptides: novel therapeutic compounds against emerging pathogens. Antimicrob Agents Chemother 43: 1-11

32. Ajesh K, Sreejith (2009) Peptide antibiotics: an alternative and effective antimicrobial strategy to circumvent fungal infections. Peptides 30: 999-1006

33. Hong J, Guan W, J G, Zhao H, Jiang X, Dai J (2015) Mechanism of tachyplesin I injury to bacterial membranes and intercellular enzymes, determined by laser confocal scanning microscopy and flow cytometry. Microbiol Res 170: 69-77

34. Edwards IA, Elliott AG, Kavanagh AM, Zuegg J, Blaskovich MAT, Copper MA (2016) Contribution of amphipathicity and hydrophobicity to the antimicrobial activity and cytotoxicity of $\beta$-hairpin peptides. ACS Infect Dis 2: 442-450

35. Pałgan K, Tykwińska M, Bartuzi Z (2015) Udział peptydów antydrobnoustrojowych w patogenezie astmy oskrzelowej. Postepy Hig Med Dosw 69: 10-13

36. Liu C, Qi J, Shan B, Ma Y (2018) Tachyplesin causes membrane instability that kills multidrug-resistant bacteria by inhibiting the 3-ketoacyl carrier protein reductase FabG. Front Microbiol 9: 825; doi: 10.3389/ fmicb.2018.00825

37. Sani MA, Separovic F (2016) How membrane-active peptides get into lipid membranes. Acc Chem Res 21: 1130-1138

38. Shai Y (1999) Mechanism of the binding, insertion and destabilization of phospholipid bilayer membranes by a-helical antimicrobial and cell nonselective membrane lytic peptides. Biochim Biophys Acta 55: 14621466

39. Sato H, Feix JB (2006) Peptide-membrane interactions and mechanisms of membranę destruction by amphipathic a-helical antimicrobial peptides. Biochim Biophys Acta 1758: 1245-1256

40. Mudhakir D, Harashima H (2009) Learning from the viral journey: how to enter cells and how to overcome intracellular barriers to reach the nucleus. The AAPS Journal 11: 65-77

41. Brogden KA (2005) Antimicrobial peptides: pore formers or metabolic inhibitors in bacteria? Nat Rev Microbiol 3: 238-250

42. Dawgul MA, Greber KE, Bartoszewska S, Baranska-Rybak W, Sawicki W, Kamysz W (2017) In vitro evaluation of cytotoxicity and permeation study on lysine- and arginine-based lipopeptides with proven antimicrobial activity. Molecules 22: 3-9

43. Zhao Y, Zhang M, Qiu S, Wang J, Peng J, Zhao P, Zhu R, Wang H, Li Y, Wang K, et al (2016) Antimicrobial activity and stability of the D-amino acid substituted derivatives of antimicrobial peptide polybia-MPI. AMB Express 6: 122; doi: 10.1186/s13568-016-0295-8
44. Berthold N, Czihal P, Fritsche S, Sauer U, Schiffer G, Knappe D, Alber G, Hoffmann R (2013) Novel apidaecin 1b analogs with superior serum stabilities for treatment of infections by Gram-negative pathogens. Antimicrob Agents Chemother 57: 402-409

45. Ye Z, Zhu X, Acosta S, Kumar D, Sang T, Aparicio C (2018) Self-assembly dynamics and antimicrobial activity of all L- and D-amino acid enantiomers of a designer peptide. Nanoscale 11: 266-275

46. Abdolhosseini M, Nandula SR, Song J, Hirt H, Gor SU (2012) Lysine substitutions convert a bacterial-agglutinating peptide into a bacterial peptide that retains anti-lipopolysaccharide activity and low hemolytic activity. Peptides 35: 231-238

47. Oliva R, Chino M, Pane K, Pistorio V, De Santis A, Pizzo E, D'Errico G, Pavone V, Lombardi A, Del Vecchio P, Notomista E, Nastri F, Petraccone L (2018) Exploring the role of unnatural amino acids in antimicrobial peptides. Sci Rep 8: 8888; doi: 10.1038/s41598-018-27231-5

48. Kowalczyk R., Harris PWR, Williams GM, Yang SH, Brimble MA (2017) Peptide lipidation - a synthetic strategy to afford peptide based therapeutics. Adv Exp Med Biol 1030: 185-227

49. Ward BP, Ottaway NL, Perez-Tilve D, Ma D, Gelfanov VM, Tschöp MH, Dimarchi RD (2013) Peptide lipidation stabilizes structure to enhance biological function. Mol Metab 2: 468-479

50. Hang H, Linder M (2011) Exploring protein lipidation with chemical biology. Chem Rev 111: 6341-6358

51. Zhang L, Bulaj G (2012) Converting peptides into drug leads by lipidation. Curr Med Chem 19: 1602-1618

52. Greber KE, Dawgul M, Kamysz W, Sawicki W (2017) Cationic net charge and counter ion type as antimicrobial activity determinant factors of short lipopeptides. Front Microbiol 8: 123; doi: 10.3389/ fmicb.2017.00123

53. Armas F, Pacor S, Ferrari E, Guida F, Pertinhez TA, Romani AA, Scocchi M, Bienincasa M (2019) Design, antimicrobial activity and mechanism of action of Arg-rich ultra-short cationic lipopeptides. PLoS ONE 14: e0212447; doi: 10.1371/journal.pone.0212447

54. Sikorska E, Stachurski O, Neubauer D, Małuch I, Wyrzykowski D, Bauer M, Brzozowski K, Kamysz W (2018) Short arginine-rich lipopeptides: from self-assembly to antimicrobial activity. Biochim Biophys Acta Biomembr 11: 2242-2251

55. Czechowicz P, Nowicka J (2018) Antimicrobial activity of lipopeptides. Post Mikrobiol 57: 213-226

56. Min KR, Galvis A, Williams B, Rayala R, Cudic P, Ajdic D (2017) Antibacterial and antibiofilm activities of a novel synthetic cyclic lipopeptide against cariogenic Streptococcus mutans UA159. Antimicrob Agents Chemother 61: e00776-17; doi: 10.1128/AAC.00776-17

57. Wang G (2012) Post-translational modification of natural antimicrobial peptides and strategies for peptide engineering. Curr Biotechnol 1: $72-79$

58. Hashizume H, Adachi H, Igarashi M, Nishimura Y, Akamatsu Y (2010) Biological activities of pargamicin A, a novel cyclic peptide antibiotic from Amycolatopsis sp. J Antibiot 63: 279-283

59. Hashizume H, Sawa R, Yamashita K, Nishimura Y, Igarashi H (2017) Structure and antibacterial activities of new cyclic peptide antibiotics, pargamicins B, C and D, from Amycolatopsis sp. ML1-hF4. J Antibiot 70: 699-704

60. Mirski T, Niemcewicz M, Bartoszcze M, Gryko R, Michalski A (2018) Utilisation of peptides against microbial infections - a review. Ann Agric Environ Med 25: 205-210

61. Chen H, Liu C, Chen D, Madrid K, Peng S, Dong X, Zhang M, Gu Y (2015) Bacteria-targeting conjugates based on antimicrobial peptide for bacteria diagnosis and therapy. Mol Pharm 12: 2505-2516

62. Jelinkova P, Splichal Z, Jimenez AMJ, Haddad Y, Mazumdar A, Sur VP, Milosavljevic V, Kopel P, Buchtelova H, Guran R, Zitka O, Richtera L, Hegerova D, Heger Z, Moulick A, Adam V (2018) Novel vancomycin-peptide conjugate as potent antibacterial agent against vancomycin-resistant Staphylococcus aureus. Infect Drug Resist 11: 1807-1817

63. Riahifard N, Tavakoli K, Yamaki J, Paranga K, Tiwari R (2017) Synthesis and evaluation of antimicrobial activity of [R4W4K]-Levoflox- 
acin and [R4W4K]-Levofloxacin-Q conjugates. Molecules 22, 957; doi: 10.3390/molecules22060957

64. Oh D, Sun J, Nasrolahi Shirazi A, LaPlante KL, Rowley DC, Parang K (2014) Antibacterial activities of amphiphilic cyclic cell-penetrating peptides against multidrug-resistant pathogens. Mol Pharm 11: 35283536

65. Johnson GA, Muthukrishnan N, Pellois JP (2012) Photoinactivation of Gram-positive and Gram-negative bacteria with the antimicrobial peptide (KLAKLAK) ${ }_{2}$ conjugated to the hydrophilic photosensitizer eosin Y. Bioconjug Chem 24: 114-123

66. Reinhardt A, Neundorf I (2016) Design and application of antimicrobial peptide conjugates. Int J Mol Sci 17: 701-722

67. Johnson GA, Ellis EA, Kim H, Muthukrishnan N, Snavely T, Pellois JP (2014) Photoinduced membrane damage of E. coli and S. aureus by the photosensitizer-antimicrobial peptide conjugate eosin-(KLAKLAK) ${ }_{2}$. PLoS ONE 9: e91220; doi: 10.1371/journal.pone.0091220

\title{
Characteristic of AMP and the effects of chemical modifications on the modulation of their antimicrobial properties
}

\author{
Marta Makowska ${ }^{\Downarrow}$, Adam Prahl, Izabela Małuch \\ Department of Organic Chemistry, Faculty of Chemistry, University of Gdańsk, Poland

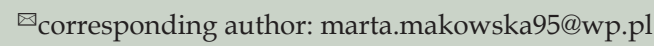

Key words: antimicrobial peptides, chemical modifications, lipopeptides, cyclization, unnatural amino acids, drugs

\section{SUMMARY}

Antibiotics have revolutionized the pharmacology market but their "golden area" passed away. The urgent need to develop new medicins with the mechanism of action different than those already used is constantly growing because of the drug-resistance of pathogenic microorganisms. The observed increasing resistance of microbes motivates scientists to design innovative strategies based on the natural peptides that exhibit antimicrobial activity. In this article we present general characterization of antimicrobial peptides and effects of chemical modifications on the modulation of their antimicrobial properties. 